ÉGYPTE

monde arabe

\section{Égypte/Monde arabe}

3| 1990

Médiateur et métaphores 2

\title{
Crise du Golfe, annexe IX : Frères musulmans :
}

Communiqué $\mathrm{n}^{\circ} 1$

Liwâ' Al-lslâm, Août 1990

Muhammad Hamid Abu-I-Nasr

\section{CpenEdition}

\section{Journals}

Édition électronique

URL : https://journals.openedition.org/ema/1894

DOI : $10.4000 /$ ema. 1894

ISSN : 2090-7273

Éditeur

CEDEJ - Centre d'études et de documentation économiques juridiques et sociales

Édition imprimée

Date de publication : 30 septembre 1990

Pagination : 253

ISSN : 1110-5097

Référence électronique

Muhammad Hamid Abu-I-Nasr, "Crise du Golfe, annexe IX : Frères musulmans : Communiqué $n^{\circ} 1$ », Égypte/Monde arabe [En ligne], 3 | 1990, mis en ligne le 08 juillet 2008, consulté le 07 juillet 2022. URL : http://journals.openedition.org/ema/1894; DOI : https://doi.org/10.4000/ema.1894

Ce document a été généré automatiquement le 7 juillet 2022

Tous droits réservés 


\section{Crise du Golfe, annexe IX : Frères musulmans : Communiqué $\mathrm{n}^{\circ} 1$}

Liwâ' Al-lslâm, Août 1990

Muhammad Hamid Abu-I-Nasr

1 Le Caire, le 11 Muharram 1411 hég. (2 août 1990)

2 Au moment où grandissaient les espoirs de la nation islamique et arabe de voir régner sur ses terres l'harmonie et la stabilité, au moment où se concentraient tous les efforts pour faire face aux ennemis qui ont liquidé leurs différends afin d'opposer un front uni à l'éveil islamique - lequel s'est propagé aux quatre coins du monde - et alors que le désaccord entre le Koweït et l'Irak semblait pouvoir se résoudre par une solution pacifique, nous avons été surpris par l'invasion irakienne du Koweït, acte horrible, consternant et stupéfiant.

3 L'on ne peut se dissimuler que cet événement important ouvre grandes les portes du mal et affecte le déroulement de la lutte des peuples islamiques aux quatre coins du monde, notamment en Palestine occupée; l'on craint que l'ennemi sioniste n'exploite l'événement à ses propres fins.

4 Nous exhortons les dirigeants irakiens à remettre en question leur entreprise, unanimement condamnée par la nation islamique et même par le monde entier. Nous exhortons aussi tous les peuples et les leaders de la nation islamique à effectuer des démarches et à user de leur influence auprès de l'Irak pour l'amener à retirer ses troupes du Koweït et à s'abstenir de toute ingérence dans les affaires de ce pays, de façon à relancer les négociations et à rechercher une solution pacifique à leur différend.

5 Nous implorons Dieu de protéger notre nation islamique - et notamment arabe - contre les dangers qui la menacent et d'inspirer à ses leaders les mesures susceptibles de repousser les périls et d'éloigner les malheurs....Le Tout-Puissant est le Plus Grand que l'on puisse appeler à l'aide et Celui qui répond le plus généreusement à l'appel. 


\section{AUTEUR}

MUHAMMAD HAMID ABU-L-NASR

Guide Suprême des Frères musulmans 